\title{
E-CHEATING: ARE STUDENTS MISUSING IT?
}

\author{
Darwin L. King, St. Bonaventure University, dking@sbu.edu \\ Carl J. Case, St. Bonaventure University, ccase@sbu.edu
}

\begin{abstract}
Undergraduates have numerous technological avenues to utilize if they choose to cheat in a class. Students, for example, can use a cell phone to store answers or use the Internet to download a research paper. Even though the problem of "e-cheating" is important to teaching faculty, little research has been conducted to examine e-cheating at the undergraduate level. This study, therefore, was conducted to empirically investigate student behavior and perceptions. Results suggest that although cheating is common among students, e-cheating is not prevalent.
\end{abstract}

Keywords: Academic integrity, e-cheating, ethics, undergraduates, empirical survey

\section{INTRODUCTION}

"E-cheating" or electronic cheating can be defined as using information technology (IT) to aid in the process of cheating in a class. This includes the use of personal digital assistants (PDAs), camera or picture cell phones, two-way pagers, programmable calculators, computers, the Internet, and so on to gain an unfair advantage. Because ethics are an important component of the information systems (IS) curriculum, the authors hope to gather information on how many students choose to violate the ethical practices taught in the classroom.

One U.S. study found that over $90 \%$ of students indicated that they owned a cell phone [12]. Cell phones can silently vibrate to inform the student that a text message has arrived and can be used to access the Internet in order to locate information for a quiz or exam [8]. Moreover, PDAs can store a wealth of information including graphics, databases, text, and spreadsheets that could prove useful to a cheating student. Sophisticated programmable calculators can also store an entire essay or outline summary of exam topics. The Internet can be utilized to cut and paste information needed for a quiz or exam. Finally, twoway pagers can be utilized to send and receive messages similar to the process of passing notes in class. An unethical student may decide to use any or all of these technological products in an effort to cheat on exams, research papers, or homework.
Considerable research has been conducted examining student cheating in general, but little study has been performed on student cheating (e-cheating) utilizing IT. Therefore, this paper reviews student perceptions of both their own cheating as well as their estimate of e-cheating by other students. Results will assist educators in determining if adjustments are needed in the instruction of ethical and moral principles.

\section{PREVIOUS RESEARCH}

Student academic dishonesty has been linked to later unethical behavior in the business environment [5]. According to Webster's dictionary, academic integrity can be defined as "an adherence to a code of academic values" [6]. Maintaining academic integrity is an important goal for educators and students alike. Mason stresses that educators must take an active role in an effort to reduce academic cheating. Today this certainly includes e-cheating with students utilizing the most modern technological devices.

Lyer and Eastman [4] found that nonbusiness students are more likely to cheat than business students. This may be the result of emphasizing ethical principles in a majority of business subjects. For example, IS and accounting texts often include ethics segments or ethics cases in numerous chapters. With the discovery of major accounting frauds in recent years, the importance of ethical behavior cannot be understated. Scanlon feels, however, that technology has made it easier for students to cheat thereby increasing academic dishonesty [9].

Another study found that faculty beliefs concerning the frequency of student cheating were related to two critical faculty behaviors [2]. These included faculty prevention efforts utilized in the course and the process of challenging students suspected of misconduct. This supports the use of generic (nonprogrammable) calculators by students when taking exams in class. Many institutions provide faculty with this type of calculator to prevent student cheating by utilizing a sophisticated calculator with a large amount of memory. Other IT controls must also be employed to remove the opportunity to commit the fraudulent act. Finally, if a student is suspected of cheating, there must be immediate discipline employed in an effort to send a message to other students that unethical behavior will not be tolerated. 
Recent studies have also shown that both IT integrity and IT security are major information technology ethics factors [7]. This suggests to educators that in an effort to maintain academic integrity in a rapidly changing technological environment, both of these concepts must be emphasized to students. This study also found that neither of these variables showed any significant variance based on gender or age.

Additional research indicates that educators must emphasize moral sensitivity and judgment in the student's education [3]. This enables the students to make decisions that allow them be behave in an ethical manner on a regular basis. Ethical sensitivity and judgment training aids students in resisting "situational effects" encountered both as a student and later in the business world.

Industry professional organizations including the Association of Computing Machinery and the Institute of Electrical and Electronics Engineers have emphasized the need for more ethics training in computer science and information systems programs [10]. This training must include significant discussion of both ethical precepts and professional codes of conduct. In particular, codes of conduct should clearly summarize ethical principles that must be understood by all students.

As mentioned earlier, the use of the Internet to download completed research papers for little or no cost is an increasing ethical problem for educators. One study has shown that online MIS courses do not appear to suffer significantly from "ringers" [11]. This small study found that others (ringers) doing the online distance work for registered students were not a significant problem. The authors credit small classes and the large amount of contact maintained with each student as the reason for low unethical behavior.

Additional research has shown that educators must be aware that ethical training must include the perceived social acceptability of the activity or the perceived legality of the decision or both [13]. Walstrom stresses that when instructing students regarding ethical behavior, the legal ramifications of concepts such as intellectual property laws must be emphasized. Training on what is socially acceptable in a particular environment is also critical.

Finally, researchers advocate for continued ethics education and training by businesses and professional organizations to reinforce to graduating students the importance of life-long ethical behavior [1]. Higher education faculty must also emphasize the importance of ethical behavior. Because e-cheating is an unethical behavior that is of prime importance to IS educators, the authors developed a survey to collect associated data. Based upon current student behavior, educators may need to adjust their instruction in ethical principles and behavior. By providing students with an ethical foundation that they will use following graduation, this should positively impact the ethical climate of society in general.

\section{RESEARCH DESIGN}

This study employs a survey research design. The research was conducted at a private northeastern U.S. university. A Student Technology Behavior instrument was developed and administered during the last week of the spring and fall 2006 semesters. The sample had a $100 \%$ response rate and included a variety of courses such as BIS-310 "Business Information Systems", BIS-335 "System Analysis and Design", ACCT-201 "Introduction to Financial Accounting", ACCT-202 "Introduction to Managerial Accounting", and MSC-413 "Business Policy." A convenience sample of class sections was selected in order to maximize student participation. The class sections were conducted by a variety of faculty.

The survey instrument was utilized to collect student demographic data and examine student behavior and perceptions regarding e-cheating. The survey requested that each student estimate the number of times during the semester that they cheated on exams and/or homework, used information technology when cheating, downloaded and submitted Internet papers as their own work, and other unethical activities. The survey was administered during the final week of the 15 -week semester and all surveys were anonymous. Moreover, students were informed that results would have no effect on their semester grade.

\section{RESULTS}

A sample of 423 usable surveys was obtained. Sixtyfour percent of the respondents were male and $36 \%$ were female. The response rate by academic class was almost equally distributed among Freshmen, Sophomore, Junior, and Senior classes. Twenty-six percent of respondents were freshmen, 22\% were sophomores, $21 \%$ were juniors, and $30 \%$ were seniors.

E-cheating activity was examined to determine the type of cheating activity committed (Table 1). Results illustrate that although $15 \%$ of students 
indicated cheating on an exam, only four percent of students admitted using IT to cheat on an exam. Fourteen percent stated that he/she let another student copy from their exam. Thirty-four percent of the students indicated permitting another student to copy their homework. Only four percent admitted to downloading a research paper from the Internet and submitting it as his/her own work.

Overall, forty-three percent of the students admitted to some type of unethical behavior including cheating on exams either with or without IT, letting others copy their homework or exams, downloading research papers as their own work, or cutting and pasting information from the Internet and not citing the source of the material. This percentage is alarmingly large and should alert IS educators of the need for more teaching of ethical principles and practices. This includes, of course, the ethical use of IT.

One noteworthy result is with regard to the number of times that students commit an unethical act. Students admit to cheating on exams an average of 4.5 times per semester, cheating on exams with IT tools 4.0 times per semester, letting others copy their homework 5.6 times per semester, and downloaded papers from the Internet to submit as their own work 5.8 times per semester. Even though only $4 \%$ of students cheated on exams using IT, they admit to this behavior quite frequently each semester. Overall, the average student reported performing approximately 10 unethical actions during the semester.

\section{<Insert Table 1 here>}

The survey also asked students if they had taken an online course. Table 2 illustrates that $25 \%$ of the students reported that they had taken such a course. The survey included a question on how easy it would be to cheat on the online exams. Nineteen percent of the students felt that it was very easy to cheat on an online exam, 35\% thought it would be somewhat easy, $34 \%$ said it would be difficult and $11 \%$ stated it would be very difficult. Overall, $54 \%$ thought it would be very or somewhat easy to cheat on an online exam.

\section{<Insert Table 2 here $>$}

The students were also asked on the survey to estimate the percentage of their fellow students who cheat on exams, homework, Internet projects, and research papers. Students indicated that the most common activity was cheating on homework. This was followed by unethical behavior related to Internet projects, exams, and term papers. Students estimated that $38 \%$ of students cheat on homework, $31 \%$ cheat on Internet projects, $23 \%$ cheat on exams, and $22 \%$ cheat on term papers. If the student estimates of these activities are accurate, there is a critical need for more emphasis on ethical behavior in the classroom. In particular, Internet projects, which are assigned in many IS, must be closely monitored in order to minimize unethical behavior. It is possible that unethical behavior allowed to persist during the student's college career will likely continue when they accept their first job and could result in some type of discipline imposed.

\section{< Insert Table 3 here $>$}

\section{CONCLUSIONS AND FUTURE RESEARCH}

Results suggest that cheating is common among undergraduates. Forty-three percent of respondents admitted to at least one type of unethical behavior. The survey results from this limited population show that e-cheating on exams is not currently a major problem. Only four percent of the students indicated using IT to cheat on an exam. A larger problem, which may not be technology related, is that $14 \%$ of the students surveyed allowed others to copy from their exam.

Furthermore, the survey results indicate that only four percent of students admit to cheating on exams using IT. However, those students who do commit this act do it frequently. These students admit to cheating using IT four times each semester. The same is true with downloading Internet papers and submitting the work as their own. Only four percent of students admitted to this deed but they committed the act an average of 5.83 times each semester. Even though the number of students is small, the number of unethical actions is substantial.

It also appears that students believe cheating is fairly common among the student body. Respondents perceive that nearly $40 \%$ of students cheat on homework, 31\% cheat on Internet projects, 23\% cheat on exams, and $22 \%$ cheat on term papers. These figures are substantial and require appropriate action on the part of educators to reduce their frequency. Preventative controls may be needed to minimize unethical behavior before it begins. Appropriate discipline procedures clearly stated in the syllabus are certainly a reasonable control. In addition, the university's ethics policy would make an appropriate addition to each syllabus. 
There are several important implications as a result of these findings. One implication is that e-cheating is in its infancy with regard to undergraduate students. Currently only four percent of the students admit to cheating on exams using IT. Those four percent, however, used IT an average of four times per semester to cheat. A control such as requiring school provided generic calculators on all exams is a reasonable preventative measure which eliminates the use of sophisticated programmable calculators that may contain subject summaries or spreadsheets.

A second implication is that students perceive that their peers are more unethical. Although $15 \%$ of students indicated cheating on an exam, students believe that $23 \%$ of other students cheat on exams. Only four percent admitted unethically downloading Internet papers, but respondents perceived that 31\% of other students cheat on Internet projects and 22\% cheat on term papers.

A third implication is that a majority of students feel that it is very easy or somewhat easy to cheat on an online exam. Because online courses are increasingly utilized, student unethical behavior may be a concern for educators.

A fourth implication is that homework projects must receive more scrutiny. Thirty-four percent of the students admit to allowing others to copy their homework. For those indicating this behavior, the incidence per individual per semester was 5.6. Even though this may not be completely an IT issue, students often utilize IT to complete homework. Because copying homework is by far the most common form of unethical behavior, educators may need to focus more effort in this area. It appears that student often believe that there is really nothing wrong with helping another student by providing the answers to homework projects.

A final implication is that students must be informed that business professional organizations from the Association of Computing Machinery to the American Society of Certified Public Accountants profess a code of ethics. Students must be made aware that upon graduation, ethical principles and practices continue to be paramount. Students who follow ethical practices while in college may likely continue that practice on the job. As a result, it is important for IS educators to establish a more positive ethical environment in each course.

One limitation of this study is a function of sample size. A larger sample size, use of additional universities, and more equal distribution of respondents by academic class and gender would increase the robustness of results. Another limitation relates to the self-reported nature of the survey. Students are using recall thus recency effects may occur. In addition, the Hawthorne Effect may be a factor.

Future research should be directed at examining the specific technological tools available to students and the opportunities for their abuse. Findings from such research would be useful in better explaining the type of ethical training that should be provided in the IS curriculum. Overall, the current results and future research are important pedagogical findings that will assist IS faculty is improving student undergraduate education and technological behavior.

\section{REFERENCES}

1. Halawi, L., \&Karkoulian, S. (2006). Ethical Attitudes of Business Information Systems Students: An Empirical Investigation. Issues in Information Systems, VII(2), 175-178.

2. Hard, S., Conway, J. M., \& Moran, A. C. (2006). Faculty and College Student Beliefs about the Frequency of Student Academic Misconduct. The Journal of Higher Education, 77(6), 10581080.

3. Harris, J. K. (2006). Ethical Perspectives In Information Security Education., Issues in Information Systems, VII(2), 179-181.

4. Lyer, R. \& Eastman, J. K. (2006). Academic Dishonesty: Are Business Students Different From Other College Students? Journal of Education for Business, Nov/Dec, 101-111.

5. Mason, K. (2006). Student Integrity. The Business Review, Vol. 6, Issue 1, 297-301.

6. Merriam-Webster Dictionary (1997).

7. Peslak, A. R. (2006). An Exploratory Investigation of Information Technology Ethics Factors. Issues in Information Systems, VII(2), 339-343.

8. Richardson, A. (2002). High-tech cheating: Where there's a will, there's a gadget. Black Issues in Higher Education, 19(11), 32.

9. Scanlon, P.M. (2004). Student Online Plagiarism: How Do We Respond?. College Teaching, 51, 161-165.

10. Schmidt, C. \& Boncella, R. J. (2006). A Framework for an Ethics Course for the Information Technology Student, Issues in Information Systems, VII(2), 13-17.

11. Schultz, T. \& Grayson, J. (2006). Ringers in Online MIS Courses. Issues in Information Systems, VII(2), 341-345.

12. Totten, J. W., Lipscomb, T. J., Cook, R. A., \& 
Lesch, W. (2005). General Patterns of Cell Phone Usage Among College Students: A FourState Study. Services Marketing Quarterly, 26(3), 13.

13. Walstrom, K. A. (2007). Social and Ethical Impacts on Information Ethics Decision Making.
Journal of Computer Information Systems, XLVII(2), $1-8$.

\section{TABLES AND FIGURES}

Table 1. Type of Cheating Activity

\begin{tabular}{||l|r|c||}
\hline \multicolumn{1}{|c|}{ Activity } & \multicolumn{1}{c|}{$\begin{array}{c}\text { \% of } \\
\text { Respondents }\end{array}$} & $\begin{array}{c}\text { Avg. Number } \\
\text { Times/Semester }\end{array}$ \\
\hline \hline Cheated on an exam & $15 \%$ & 4.5 \\
\hline Cheated on exams using IT & $4 \%$ & 4.0 \\
\hline Let others copy from my exam & $14 \%$ & 2.8 \\
\hline Let others copy my homework & $34 \%$ & 5.6 \\
\hline Downloaded Internet papers as his/her own work & $4 \%$ & 5.8 \\
\hline \hline At least once unethical activity from above (unduplicated) & $43 \%$ & 9.9 \\
\hline \hline
\end{tabular}

Table 2. Ease of Cheating on Online Course Exams (Students had taken an online course)

\begin{tabular}{||l|c||}
\hline \multicolumn{1}{|c|}{ Ease of Cheating } & $\begin{array}{c}\text { Percent of } \\
\text { Students }\end{array}$ \\
\hline \hline Very easy to cheat & $19 \%$ \\
\hline Somewhat easy to cheat & $35 \%$ \\
\hline Difficult to cheat & $34 \%$ \\
\hline Very difficult to cheat & $11 \%$ \\
\hline
\end{tabular}

Table 3. Student Estimates of Cheating by Other Students

\begin{tabular}{||l|c||}
\hline \multicolumn{1}{|c|}{ Activity } & $\begin{array}{c}\text { Percent of } \\
\text { Students }\end{array}$ \\
\hline \hline Homework & $38 \%$ \\
\hline Exams & $23 \%$ \\
\hline Term Papers & $22 \%$ \\
\hline Internet Projects & $31 \%$ \\
\hline
\end{tabular}

